\title{
ECOLOGICAL STUDIES ON CERTAIN PIERCING SUCKING PESTS INFESTING SUGAR BEET CROP AND THEIR ASSOCIATED NATURAL ENEMIES IN SHARKIA GOVERNORATE, EGYPT.
}

Aml Z. N. Al - Habshy; A. A. Abd - Elsamed and O. M. O. Mohamed

Plant Prot. Res. Inst., Agric. Res. Cent., Dokii, Giza, Egypt

\begin{abstract}
The present work was carried out at Diarb- Nigm district, Sharkia Governorate, during the two successive growing sugar beet seasons 2010/2011 and $2011 / 2012$, to study the population fluctuation of certain sucking pests and their associated natural enemies. The obtained results showed that the population fluctuation of common aphid Myzus perseica (Sulzer) and Aphis craccivora Koch, leafhopper Empoasca decipiens (Paoli), Empoasca decedens (Paoli), Nezara verdulla Lins and two-spotted spider mite Tetranychus cucurbitacearum (Sayeg) and their associated natural enemies of predator mite Amblyseius swirskii as well as the effect of temperature and relative humidity. The aforementioned insect pest species were collected by two different methods from sugar beet plants using direct counting (plant sample) and sweep net. The obtained results showed that the plant sample proved to be the best method to collect aphid, green bug insect species and twospotted spider mite of the present work, while the sweep net proved to be the best technique to collect the leafhopper insect species. The seasonal abundance of $M$. persicae on sugar beet plants recorded two peaks for $M$. persicae. The first one was occurred at $2^{\text {nd }}$ week of December, the second peak was found at $4^{\text {th }}$ week of January. The leafhopper $E$. decipiens and E. decedens were recorded two peaks, the first peak was recorded at $2^{\text {nd }}$ week of Novamber, while the second peak was occurred at $1^{\text {st }}$ week of February for $E$. decipiens and $E$. decedens for the two seasons, respectively. Two peaks were recorded for $N$. verdulla the first one was occurred at $2^{\text {nd }}$ week of December, while the second peak was recorded at $1^{\text {st }}$ week of February. The mite (adult and immature stages) recorded two peaks, the first peak of adults and immature stages at $2^{\text {nd }}$ week of October 2010/2011 and $4^{\text {th }}$ week of October 2011/2012, respectively. The first peak of eggs at $2^{\text {nd }}$ week of October $2010 / 2011$ and $1^{\text {st }}$ week of November 2011/2012, respectively. The second peak was recorded for mite (adult, immature stages and eggs), the second peak of adults at $3^{\text {rd }}$ week of March 2010/2011 and $4^{\text {th }}$ week of March 2011/2012, of immature stages at $2^{\text {nd }}$ week of November 2010/2011 and $3^{\text {rd }}$ week of March 2011/2012 and of eggs at $4^{\text {th }}$ week of October 2010/2011 and 3rd week of March 2011/2012, respectively. Two peaks were recorded for predator mite $A$. swirskii. The first peak at $4^{\text {th }}$ week of February 2010/2011and 2011/2012, respectively. The second peak was recorded at $4^{\text {th }}$ week of March 2010/2011and 2011/2012, respectively. This research aims to utilize the obtained results in developing the IPM programs against these pests on sugar beet plants through activation the effect of both temperature and relative humidity on insect numbers.
\end{abstract}

\section{INTRODUCTION}

Sugar beet, Beta vulgaris L., growing for sugar production and it is considered as one of the two important sugar beet crops in the world and Egypt (Amin, 2005 and Fouad, 2011). The piercing sucking insect such as 
the aphids (Myzus perseica (Sulzer) and Aphis craccivora) Koch, leafhoppers (Empoasca decipiens (Paoli) and Empoasca decedens) (Paoli) , Green bug Nezara verdulla L. and two - spotted spider mite Tetranychus cucurbitacearum (Sayed) are considered among the economic pests of sugar beet plants at present (Farag et al., 1998). Arthropod predators of mites and spiders are considered the main elements for minimizing the population of different pests (Omar and Mohamed 2007). The present study aimed toinvestigate the population fluctuation of certain piercing sucking pests infesting sugar beet plants and their associated natural enemies as well as the relation ship between these pests and climatic factors.

\section{MATERIAL AND METHODS}

\section{Experimental Design:}

The experiment was carried out at Diarb- Nigm district, Sharkia Governorate, during the two growing sugar beet seasons of 2010/2011 and 2011/2012 to study the population fluctuation of certain sucking pests and their natural enemies. One fedden $\left(4200 \mathrm{~m}^{2}\right)$ was chosen and divided into three plots. Sampling started when the age of sugar beet plants reached about 21-28 days after sowing and continued at weekly intervals throughout the growing seasons in 2010/2011 and 2011/2012 seasons. The following procedures of sampling were adopted. The field was planted with sugar beet on September during two seasons. The normal agricultural practical were followed and no pesticides treatments were applied during the whole experiment period.

\section{Sample technique}

a)Direct counting, 30 leaves representing different strata, viz. terminal, middle and bottom parts were taken randomly. These leaves were examined in the laboratory using a stereoscopic binocular microscope and the total number of existing of aphid, mite and predatory mite on both surfaces of the leaves were recorded.

b) Sweep net, $30 \mathrm{~cm}$ diameter and $60 \mathrm{~cm}$ deep. Each sample consisted of 100 double strokes were taken from both diagonal directions of the experimental area. Each sample was kept in a tight closed paper bag and transferred to the laboratory for inspection by stereoscopic binocular microscope and the collected leafhoppers and green bug were killed by chlorophorm, sorted into species and identified according to the work of (Ribaut, 1952; Nielson, 1968 and Hegab et al., 1989). For clearing the effect of certain weather factors such as temperature and atmospheric relative humidity on the population density of the studied insect pests the daily means of the two factors were provided by the Meteorological Central Laboratory for Agricultural Climate- Agricultural Research Center during the whole period of the two seasons (2010/2011 and 2011/2012). Counts of captured leafhoppers were recorded for each sample. The obtained data were statistically analyzed according to (Snedcor and Cochran, 1982) to show the influences of temperature and relative humidity on population density of the tested piercing sucking pests studied. 


\section{RESULTS AND DISCUSSIONS}

\section{Survey of homopterous insects on sugar beet plants}

\section{a- Aphid species:}

Survey was conducted during two successive seasons on sugar beet plants in Diarb-Nigm, district, Sharkia Governorate. The obtained results revealed that presence of the following aphids species $M$. persicae and Aphis craccivora recorded total numbers of 3417 - 3590 and $94-104$ insects / plant sample for the two seasons, respectively and the results were showned in Table (1).

b- Leafhopper insects:

The data presented in Table (1) showed that two leafhopper species belonging to family Cicadellidae were found on sugar beet plants. The collected leafhopper species were according to their abundance as follows: E. decipiens recorded total numbers of 1716 and 1159 insects / sweep net and $E$. decedens recorded total number of 382 and 344 insects/ sweeping net for the two seasons, respectively.

Table (1): Total number of some piercing sucking insects, mite and mite predatory collected from sugar beet plants by using plant sample and sweep net at Diarb-Nigm district, Sharkia Governorate during 2010 / 2011 and 2011 / 2012 seasons.

\begin{tabular}{|c|c|c|c|c|c|}
\hline \multirow{2}{*}{\multicolumn{2}{|c|}{ Insect species }} & \multicolumn{2}{|c|}{$2010 / 2011$} & \multicolumn{2}{|c|}{2010 / 2012} \\
\hline & & Plant sample & Sweep net & Plant samples & Sweep net \\
\hline \multicolumn{2}{|c|}{ M. persicae } & 3417 & 22 & 3590 & 52 \\
\hline \multicolumn{2}{|c|}{ A. craccivora } & 94 & 2 & 104 & 5 \\
\hline \multicolumn{2}{|c|}{ E. decipiens } & 210 & 1716 & 145 & 1159 \\
\hline \multicolumn{2}{|c|}{ E.decedens } & 78 & 382 & 93 & 344 \\
\hline \multicolumn{2}{|c|}{ N. verdulla } & 24 & 139 & 19 & 140 \\
\hline \multicolumn{2}{|c|}{ Mite predators } & 244 & - & 243 & - \\
\hline \multirow{3}{*}{ 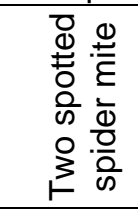 } & Adults & 1225 & - & 586 & - \\
\hline & Immature & 3799 & - & 2613 & - \\
\hline & Eggs & 6261 & - & 4019 & - \\
\hline
\end{tabular}

\section{c- Green bug}

The green bug, was found in sugar beet plants. The total numbers of $N$. verdulla was 139 and 140 individuals / sweep net for the two seasons, respectively Table (1).

\section{d- Mites:}

The mites, was found in sugar beet plants. The total numbers of adults were 1225 and 586 individuals / plant sample, while the total numbers of immature stages were 3799 and 2613 individuals / plant sample. Also the total numbers of egg stages were 6261 and 4019 eggs/ plant sample. The total numbers of predatory mite was 244 and 243 individuals / plant sample (direct ccounting) during 2010/2011 and 2011/2012 seasons, respectively 
AmI Z. N. Al- Habshy et al,

2. Seasonal abundance of the dominant homopterous insects, mites and mite predatory on sugar beet plants.

a- Aphid insects:

The data illustrated in Fig. (1) showed that the M. persicae recorded two peaks during 2010/2011and 2011/2012 seasons on sugar beet plants. The first one was occurred at $2^{\text {nd }}$ week of December with a total numbers of 275 and 316 insects / sample for the two seasons, respectively. The second peak was recorded at $4^{\text {th }}$ week of January with a total numbers of 417 and 548 insects /sample for the two seasons, respectively. These results agree with the findings of (Iskander, 1982; Geza, et al., 1999; Peter, 2006; Muska, 2007 and Fouad, 2011) who mentioned that M. persicae had two peaks on sugar beet crop.
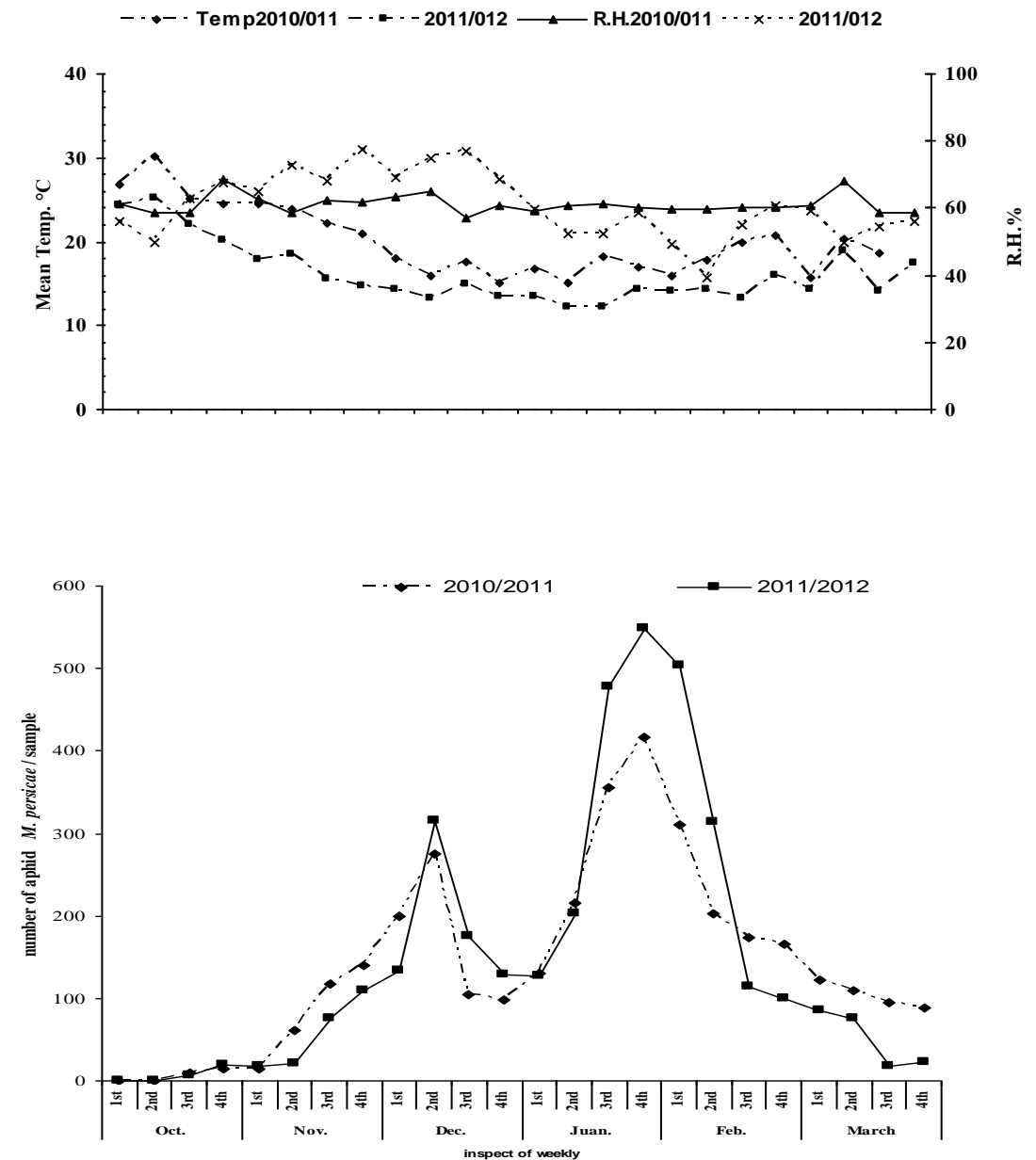

Fig.(1) :Seasonal abundance of $M$. persicae infesting sugar beet plants collected by direct counting at Dirab-Nigm district Sharkia Governorate during2010/011and 2011/012 seasons 


\section{b- Leafhopper insects:}

The leafhopper, E. decipiens and E. decedens were recorded two peaks during the two seasons. The first peak was recorded at $2^{\text {nd }}$ week of November with a total numbers of 166, 135 and 35, 29 insects / sample for the two seasons, respectively. The second peak was occurred at $1^{\text {st }}$ week of February with a total numbers of 195, 117 and 41,37 insects / sample for the two seasons, respectively Fig. (2). These results partially agree with the findings of (Guirguis, 1985; Munyaneza et al., 2005; Munyaneza et al., 2006; Joseph et al., 2010 and Talebil, et al., 2010) who mentioned that $E$. decipiens and $E$. decedens had one peak on sugar beet plants.

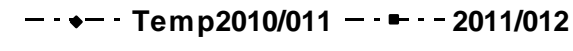

$\longrightarrow$ R.H.2010/011 - - ×- - 2011/012
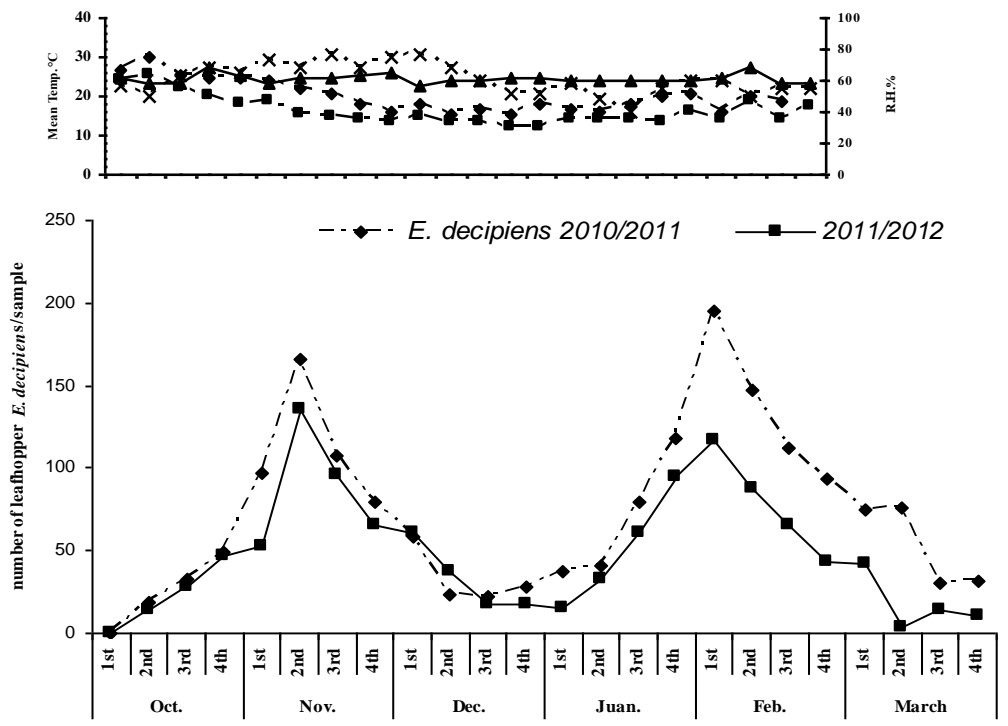

inspect of weekly

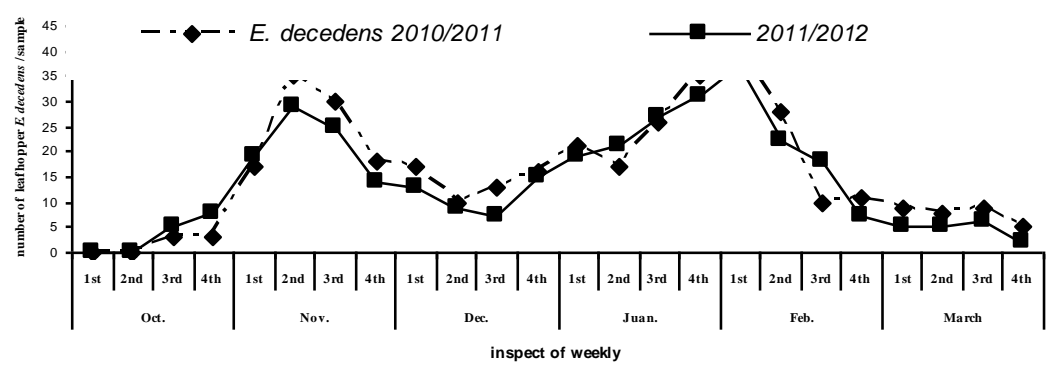

Fig.(2) :Seasonal abundance of E. decipiens and E. decedens infesting sugar beet plants collected by sweep net at Dirab-Nigm district Sharkia Governorate during 2010/011and 2011/012 seasons 


\section{c-Green bug :}

The green bug $N$. verdulla was recorded two peaks during the two seasons. The first peak was occurred at $2^{\text {nd }}$ week of December with a total numbers of 11 and 15 insects / sample for the two seasons, respectively. The second peak was recorded at $1^{\text {st }}$ week of February with a total numbers of 18 and 16 insect / sample for the two seasons, respectively, Fig. (3). These results agree with the findings of (El-Zoghby and Amal, 2003) who mentioned that $N$. verdulla had two peaks on sugar beet plants.

d-Mites:

The two spotted spider mite $T$. cucurbitacearum (adults, immature and eggs) was recorded two peaks during the two seasons. The first peak was occurred at $2^{\text {nd }}$ week and $4^{\text {th }}$ week of October with a mean numbers of 140 and 76 individuals / leaf for the adults and 291 and 225 individuals /sample for the immature, while at $2^{\text {nd }}$ week of October and $1^{\text {st }}$ week of November with a mean numbers of 610 and 392 individuals /sample for the eggs for the two seasons, respectively. The second peak was recorded at $3^{\text {rd }}$ week of March and $4^{\text {th }}$ week of March with a mean numbers of 125 and 85 individuals /sample for the adults, while at $2^{\text {nd }}$ week of November and $3^{\text {rd }}$ week of March with a mean numbers of 315 and 210 individuals / sample for the immature and at $3^{\text {rd }}$ week of November and $3^{\text {rd }}$ week of March with a mean numbers of 405 and 401 individuals /sample for the eggs for the two seasons, respectively, Fig. (3).

\section{Predator mite (Amblyseius swirskii):}

The population fluctuation of $A$. swirskii on sugar beet crop was recorded two peaks for the two seasons. The first peak was occurred at $4^{\text {th }}$ week of February with a mean numbers of 30 and 37 individuals/sample for the two seasons, respectively. The second peak was recorded at $4^{\text {th }}$ week of March with a mean numbers of 35 and 43 individuals /sample for the two seasons, respectively, Fig. (4).

These results agree with the findings of (Farag et al., 1998) recorded that the phytophagous and its predaceous mites on leguminous vegetables in Kaliobia and Giza Governorates throughout one year. They found that, the tetranychid mite $T$. urticae was the most dominant phytophagous species found on the crop. Also the population fluctuation of $T$. urticae and three phytoseiid predators were studied under greenhouse and field on kidney been (Phaseolus vulgaris) by (Youngln et al.,1998). They showed that the mite $T$. urticae and its predatory mites were found throughout the period of the study. (Amir and Kandeel, 1988) studied that the incidence of insects and mites associated with lentil plants as a legume crop at Zagazig district, Sharkia Governorate during the two seasons 1984 / 1986. They studied the population density and seasonal fluctuation of insect pests. 

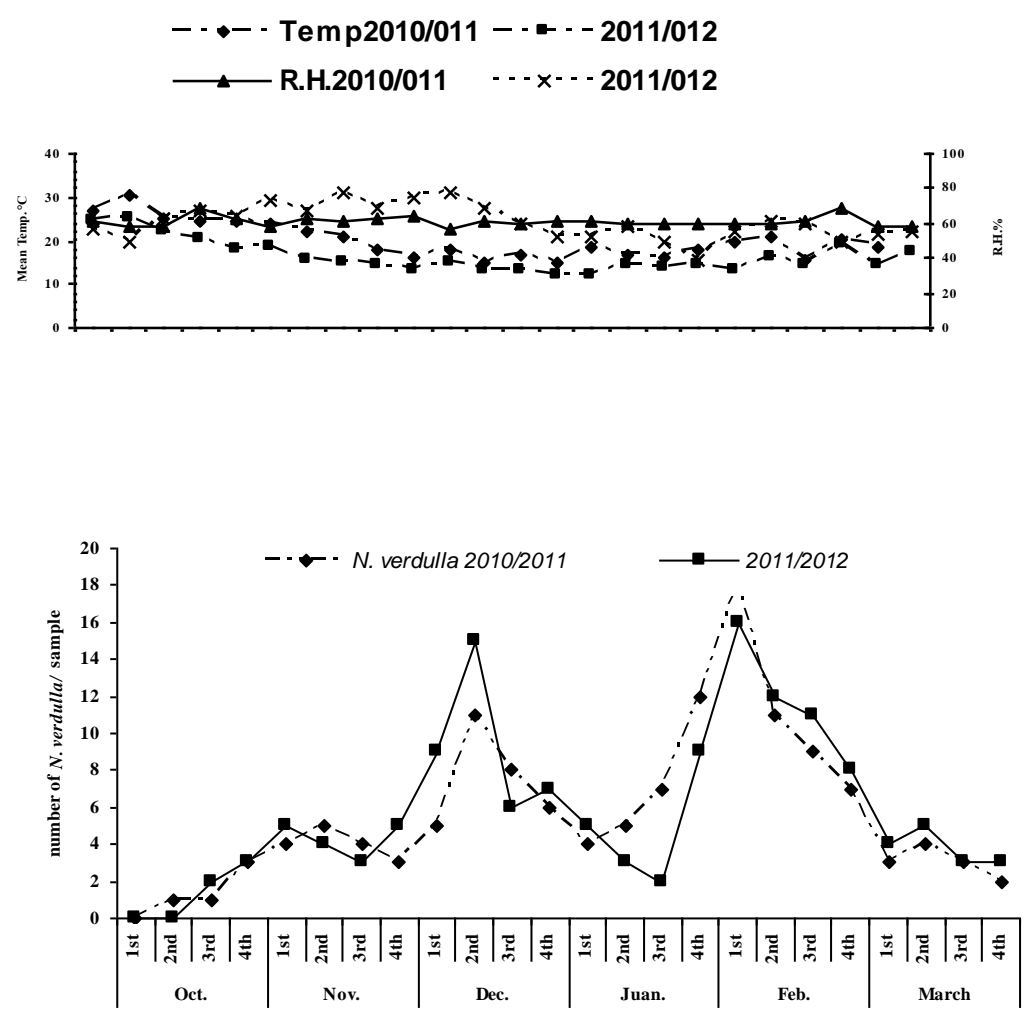

inspect of weekly

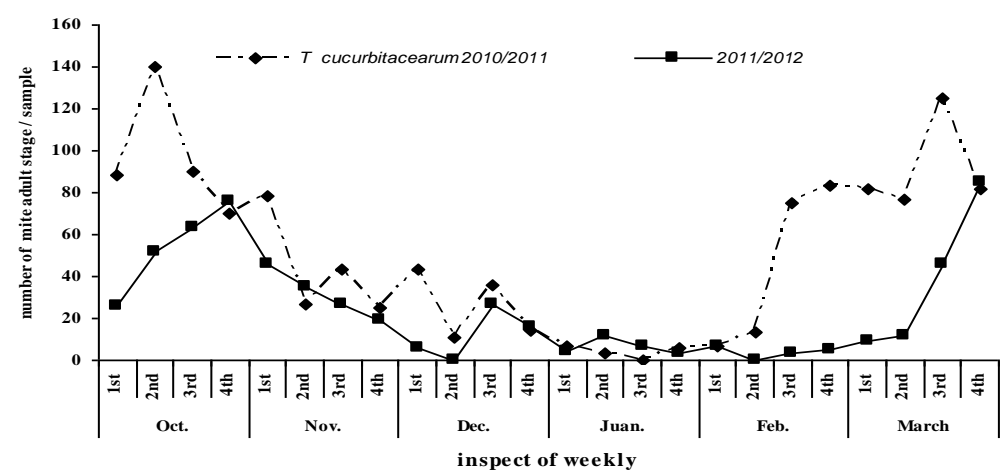

Fig.(3) :Seasonal abundance of $\boldsymbol{N}$. verdulla by sweep net and mite adults by direct counting infesting sugar beet plants collected at Dirab - Nigm district Sharkia Governorate during2010/011 and 2011/012 seasons 
AmI Z. N. Al- Habshy et al,

$\begin{array}{r}-\cdot-\text { Temp2010/011 } \\ \longrightarrow \text { - }-\cdot-2011 / 012 \\ \hline\end{array}$
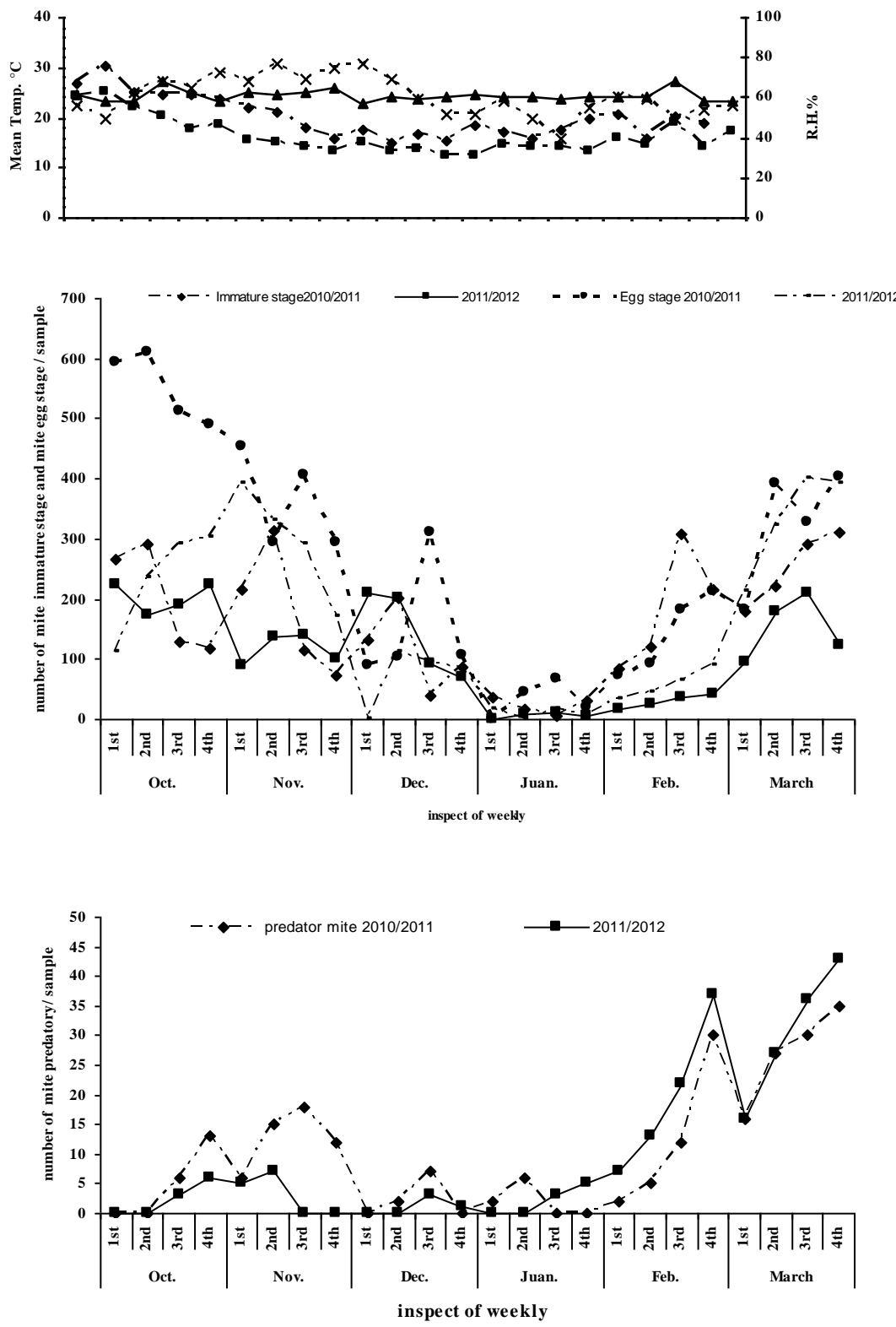

Fig.(4) :Seasonal abundance of mite immature, mite egg stage and predatory mite infesting sugar beet plants collected by direct counting at Dirab - Nigm district Sharkia Governorate during 2010/011 and 2011/012 seasons 
3. Effect of maximum, Minimum temperature and relative humidity on the number of aphids, leafhoppers, green bug, mites and mite predatory infesting sugar beet plants

\section{1) - M. persicae}

The results obtained appeared that the correlation coefficient between $M$. persicae and maximum temperature was highly significant and insignificant $\left(r_{1}=0.596^{* *}\right.$ and 0.303$)$ in the two seasons, respectively, Table (2). The number of $M$. persicae was highly significant and significant correlation with minimum temperature $\left(r_{2}=0.541^{* *}\right.$ and $\left.0.423^{*}\right)$ in the two seasons, respectively. While, relative humidity was insignificant and significant $\left(r_{3}=0.309\right.$ and $\left.0.562^{*}\right)$ in the two seasons, respectively.

\section{2) E. decipiens}

The correlation coefficient between $E$. decipiens and (maximum and minimum) temperature was insignificant in the two seasons. While, relative humidity was significant and insignificant $\left(r_{3}=0.0 .466^{*}\right.$ and -0.256$)$ during the two seasons, respectively.

\section{3) E. decedens}

The correlation coefficient between $E$. decedens and three weather factors were insignificant during the two seasons, respectively.

\section{4) N. verdulla}

Significant correlation coefficient was found between immature stages of $N$. verdulla and maximum temperature was significant $\left(r_{1}=0.520^{*}\right.$ and $0.396^{\star}$ ) in the two seasons, respectively. The correlation coefficient between $N$. verdulla and minimum temperature was significant $\left(r_{2}=0.452^{*}\right.$ and $0.462^{*}$ ) in the two seasons, respectively. Relative humidity was insignificant in the two seasons.

5) Adult T. cucurbitacearum .

The correlation coefficient between the adults stage of $T$. cucurbitacearum and maximum temperature was significant and insignificant $\left(r_{1}=0.531^{*}\right.$ and 0.366$)$ in the two seasons, respectively. While it was insignificant and highly significant $\left(r_{2}=0.362\right.$ and $\left.0.676^{* *}\right)$ between $T$. cucurbitacearum and minimum temperature. The correlation coefficient between $T$. cucurbitacearum and relative humidity was insignificant in the two seasons.

a) Immature stages of T. cucurbitacearum .

The correlation coefficient between the Immature stage and the three weather factors were insignificant during the two seasons.

b) Eggs of $T$. cucurbitacearum .

Significant and insignificant correlation coefficient was found between egg stages of $T$. cucurbitacearum and maximum temperature $\left(r_{1}=0.399^{*}\right.$ and 0.182 ) in the two seasons respectively. The correlation coefficient between eggs $T$. cucurbitacearum and minimum temperature was insignificant and highly significant $\left(r_{2}=0.324\right.$ and $\left.0.640^{* *}\right)$ in the two seasons, respectively. Relative humidity was insignificant in the two seasons.

6) - Predatory mite A. swirskii :

The correlation coefficient between the adults stage of $A$. swirskii 
and (maximum and minimum) temperature was insignificant. Relative humidity was insignificant and significant $\left(r_{3}=0.179\right.$ and $\left.0.455^{*}\right)$ in the two seasons, respectively.

These result conceded with those obtained by (Omar and Mohamed, 2007) studied that te effect of temperature and relative humidity on Bryobia cristata (Duges) and its predator, Lasioseius lirdquisti (Nasr and Abou Awrd) inhabiting sugar beet in Sharkia Governorate, also, they studied the simple correlation between the population fluctuation with some climatic factors and studied the interrelations between the pest mite and its mite predator. (Mohamed, 2004) who studied the population fluctuation of $T$. cucurbitacearum on sugar beet at at the two districts El-Salheia and SanAlhagar during 1999-2001. Also, he studied the simple correlation between the population fluctuations with some climatic factors and found that, $T$. cucurbitacearum showed a highly infestation on sugar beet at San- Alhagar more than El- Salheia. (Legrand et al., 2000) declared that T. urticae was very occasional in sugar beet crop. In France (Muchembled, 1999) discussed the conditions with favor the development of $T$. urticae in sugar beet crop and used acaricides for the control of this pest are presented.

Table (2): Simple correlation coefficients and partial regression between the means of maximum temperature, minimum temperature and mean relative humidity and total numbers of certain piercing sucking pests infesting sugar beet plants during 2010/2011 and 2011 / 2012 seasons.

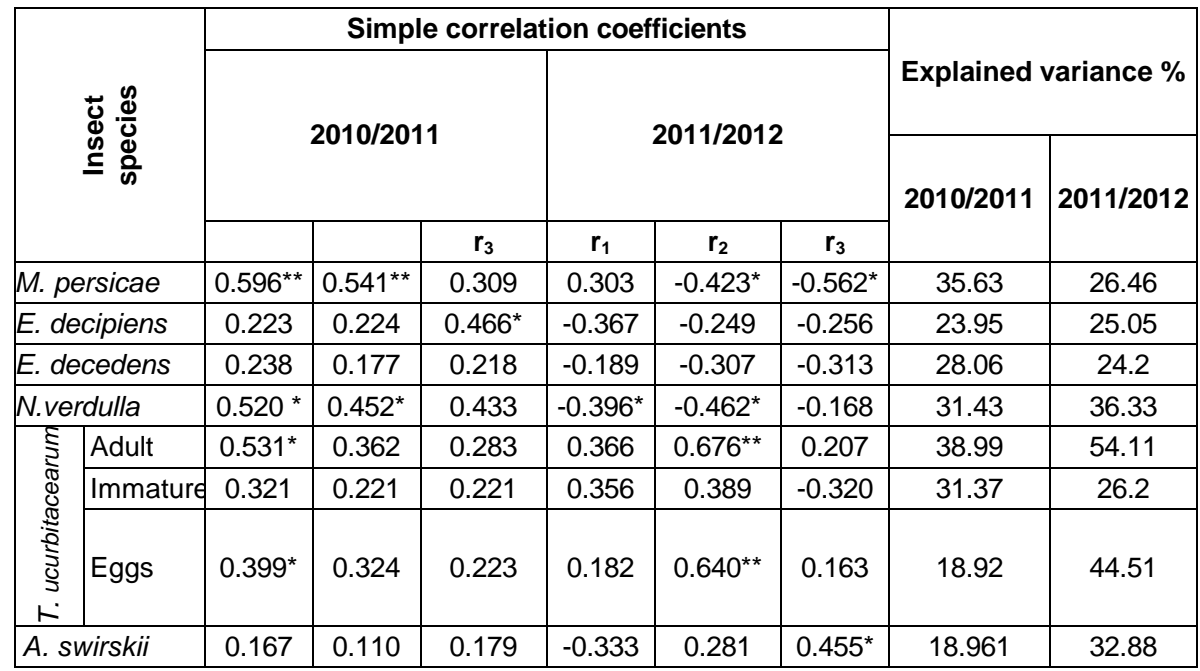

r1=correlation coefficient between max. temp. and number of insects r2=correlation coefficient between min. temp. and number of insects $r 3=$ correlation coefficient between R.H. and number of insects

4. Combined effects of meteorological factors on the numbers of aphid, leafhoppers, green bug, mite and predatory mite.

The effect of (maximum and minimum) temperatures and mean relative humidity on aphid, leafhoppers, green bug, mite and mite predatory numbers 
were estimated by calculating the partial regression analysis . E.V.\% values (Table 2) demonstrate that the adults population of $T$. cucurbitacearum in the two seasons more sensitive to changes in the considered weather factors (mean temperature and relative humidity) showed the highest values of $38.99 \%$ and $54.11 \%$, respectively. On the other hand, the least combined effects were detected to both of egg $T$. cucurbitacearum in 2010/2011 season and $E$. decedens in 2011/2012 season showing the least values of $18.92 \%$ and $24.2 \%$, respectively.

Pest species- adult two spotted spider mite interrelations:

The correlation coefficient revealed that there is highly significance negative between the pest species and adult two spotted spider mite during both seasons $\left(r=0.605^{* *} \&-0.543^{* *}\right.$, respectively) with $M$. persicae; there was highly significance negative during both seasons $\left(r=-0.611^{* *} \&\right.$ $0.570^{* *}$, respectively)with $N$. verdulla . Also, there was a highly significant negative and insignificant negative during the two seasons $\left(r=-0.600^{* *}\right.$ and $414)$ with $E$. decedens while, their were insignificance during both seasons $(r=-0.279 \&-0.258$, respectively) with E. decipiens (Table 3).

Pest species - predatory mite interrelations:

The correlation coefficient revealed that there insignificance between the pest speces and its predator during the two seasons. An exption appeared showing a significant negative between $E$. decedens with its predator during the second season $\left(r=0.463^{*}\right)$ and $N$. verdulla with its predator during the first season $\left(r=-0.431^{*}\right)$ (Table 3).

Interrelations:

Pest mite (Adult, immature and eggs) - predatory mite

The correlation coefficient revealed that there is highly significance between the pest mite stages (Adult, Immature and Egg) and its predator during the first season $\left(r=0.721^{* * *}, 0.665^{* * *}\right.$ and $0.590^{* *}$, respectively); while, their was no significance during the second season $(r=0.268,0.123$ and 0.406 respectively) (Table 3).these results coincided with those obtained by Omar and Mohamed (2007) studied that effect of temperature and relative humidity on $B$. cristata and its predator, Lasioseius lindquisti inhabiting sugar beet in Sharkia Governorate during 2004 /2005 and 2005/2006 . Also discussed the simple correlation between the mite pest and its predator as affected by temperature and relative humidity. Also, the correlation between the pest mite and its predator was tested. (Mohamed, 2004) who studied the population fluctuation of T. cucurbtacearum (Sayed) on sugar beet at the two districts, El- Salheia and San - Alhagar during 1999 - 2001. Also, he studied the simple correlation between the population fluctuation with some climatic factors and found that at, $T$. cucurbitacearum showed a highly infestation on sugar beet at more than El-Sahein. (Legrand et al., 2000) declared that $T$. urticae was very occasional in suger beet. In France, (Muchembled, 1999) discussed the conditions which favor the development of $T$. urticae in sugar beet and used acaricides for the control of this pest are presented.

\section{Pest species - Adult two spotted spider mite interrelations}

The correlation coefficient revealed that there is highly significance negative between the pest species and two spotted spider mite. An expiation 
appeared showing insignificant negative between $E$. decipiens with Adult mite plant during the two seasons $(r=-0.279$ and -0.258$)$ and $E$. decedens with Adult mite plant during the second season $(r=-0.414)$ (Table 3$)$.

Table (3): Simple correlation coefficients and partial regression between the Predatory mite Amblyseius swirskii (Athias - Hennriot) and mites with total numbers of certain piercing sucking infesting sugar beet plants during 2010/2011 and 2011 / 2012 seasons.

\begin{tabular}{|c|c|c|c|c|c|}
\hline \multirow{3}{*}{\multicolumn{2}{|c|}{ Insect species }} & Adult r & plant & mite & atory \\
\hline & & \multicolumn{2}{|c|}{$\mathbf{r}_{1}$} & \multicolumn{2}{|c|}{$r_{2}$} \\
\hline & & 2010/2011 & 2011/2012 & $2010 / 2011$ & 2011/2012 \\
\hline \multicolumn{2}{|c|}{ M. persicae } & $-0.605^{* *}$ & $-0.543^{\star \star}$ & -0.431 & -0.262 \\
\hline \multicolumn{2}{|c|}{ E. decipiens } & -0.279 & -0.258 & -0.261 & -0.283 \\
\hline \multicolumn{2}{|c|}{ E. decedens } & $-0.600^{* *}$ & -0.414 & -0.413 & $-0.463^{*}$ \\
\hline \multicolumn{2}{|c|}{ N. verdulla } & $-0.611^{\star *}$ & $-0.570^{* \star}$ & $-0.431^{*}$ & -0.381 \\
\hline \multirow{3}{*}{ 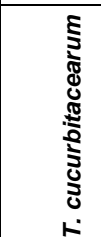 } & Adults & - & - & $0.721^{* * *}$ & 0.268 \\
\hline & Immature & - & - & $0.665^{\star \star \star}$ & 0.123 \\
\hline & Eggs & - & - & $0.590^{* *}$ & 0.406 \\
\hline
\end{tabular}

REFERENCES

El-ZOGHBY A. and A. AMAL (2003): Studies for using Beauveria bassiana (bals.) vuillemin on controlling the green stink bug Nezara viridula I. (heteroptera: pentatomidae) in sugar beet plantations in Egypt. Egyptian Journal of Biological Pest Control ; (13) : 1-2.

AMIN, G.A.M. (2005): Study of some agricultural practices on sugar beet M.S.c. Tesis, Fac. Agric., Zagazig Univ. : 157pp.

AMIR, M.M.I. and KANDEEL, M.M.H. (1988): Preliminary of insects and mites inhabiting lentil plants at zagazig district, Sharkia Governorate, Egypt, zagazig J. Agic . Res, 15 (2): 872-885.

FARAGE, A.M.I.; K.M. MAGADA and H.H.NADIA, (1998): Survey of mites inhabiting Cucurbitaceous and Leguminous vegetables in Kaliobia and Giza Governorates. J. of Agric. Res. 76 (1): 63-68.

FOUAD, H. A. M. (2011): Control some pests infesting sugar beet Sharkia Governorate. M. Thesis, Fac. Agric, Mansoura Univ., 172 pp.

GEZA, K.; P. KAROLY and N. LAJOS (1999): Flying of the aphid pests of sugar beet and changes in their individual numbers. Acta-AgronomicaOvariensis. 1999; 41(1): 15-26.

GUIRGUIS, G. Z. (1985): Studies on certain insects attacking sugar-beet in Western Desert, Egypt. Ph. D. Thesis, Fac. of Agric, Menoufiya Univ., $277 \mathrm{pp}$.

HEGAB, A. M.; M. M. EI ZOHAIRY and M. M. HELALY (1989):Survey and seasonal abundance of leafhoppers infesting certain solanacous vegetable plants in newly reclaimed sandy areas at salhia district ,Egypt, Zagazig J.Agric.Res.16(2): 175-187.

ISKANDER, A. K. (1982). Studies on certain sugar beet insects. M. Sc. Thesis, Fac. Agric, Alex Univ., 144 pp. 
JOSEPH, E. M.; M. C. JAMES; E. U. JEFFREY and L. B. JEREMY (2010) Incidence of the beet leafhopper-transmitted virescence agent phytoplasma in local populations of the beet leafhopper, Circulifer tenellus, in Washington State. Journal of Insect Science: 10 (18): 1-10.

LEGRAND, G.; A. WAUTERS; C. MUCHEMBLED and $M$. RICHARDMOTARD (2000): The common yellow spider mite, Tetranychus urticae (Koch) (Acari: Tetranchidae) in sugar beet in Europe: A new problem. Brussles, Belgium; Institute International de Recherches Better. avieres: $245-256$.

MOHAMED, O.M.O (2004): Ecological and Biological studies on some mites associated with field crops I new reclaimed area at Sharkia Governorate. Ph.D. Thesis, Fac. Agric., Al- Azhar Univ.:241pp.

MUCHEMBLED, C. (1999): Tetranychus urticae in sugar beet crop: a new pest to watch. Association Nationale Pour la Protection des Plants (ANPP) : $519-527$.

MUNYANEZA, J. E. and J. E. UPTON (2005): Beet Leafhopper (Hemiptera: Cicadellidae) Settling Behavior, Survival, and Reproduction on Selected Host Plants. J. Econ. Entomol. 98(6): 1824 - 1830.

MUNYANEZA, J. E.; J. M. CROSSLIN and J. E. UPTON. (2006): The beet leafhopper (Hemiptera: Cicadellidae) transmits the Columbia Basin potato purple top phytoplasma to potatoes, beets, and weeds. Journal of Economic Entomology, 99: 268-272.

MUSKA, F. (2007). Damaging presence of aphids on sugar beet and beet in Czech Republic historical summary until 2005. Listy-Cukrovarnicke-aReparske. 2007: 123(9/10): 284-287.

NEILSON, M. W. (1968): The leafhopper vectors of phytopathogenic viruses(Homoptera:Cicadellidae) taxonomy, biology and virus transmission. Agric .Ser .M.S.Dept.Agr.89.386.

OMAR, N.A.A. and O.M.O. MOHAMED (2007): Effect of temperature and relative humidity on Bryobia eristata (Duges) and its predator, Lasioseius lindquisti (Nasr \&Abou-Awad) inhabiting sugar beet in Sharkia Governorate, Egypt (Acari: Tetranychidae, Ascidae). J. of Appl. Sci., 22(12b): 682-690.

PETER, T.; I.T. JAN; T. MONIKA and V. PACUTA (2006): Distribution, host plants and natural enemies of sugar beet root aphid (pemphigus fuscicornis) in slovakia. Proc. Nat. Sci., Matica Srpska, 110, 221- 226.

RIBAUT,H.(1952): Homopterea Auchenorhyneques II Jassidae faunde France, $57: 1-474$.

SNEDECOR, G.W. and W.G. COCHRAN(1982): Statistical Methods. $7^{\text {th }}$ Edition. lowa State University Press, USA: PP. 365-372.

TALEBI1, A. A.; A. IZADPANAH1; S. MOHARRAMIPOUR1; Y. FATHIPOUR1 and B. NASERI (2010): Demographic study of the green leafhopper, Empoasca decipiens (Hemiptera: Cicadellidae) on four sugar beet cultivars. Appl. Ent. Phytopath.. 77 (2), 1-13.

YOUGIN, L.; G.M. KWON; S.W. LEE; H.K. RYU and O.H. RYU (1998): Density fluctuation of Tetranychus urticae and three predatory mite species (phytoseiidae) by the differently infested levels. Journal of Applied Entomol., 36 (3): 237-243. 


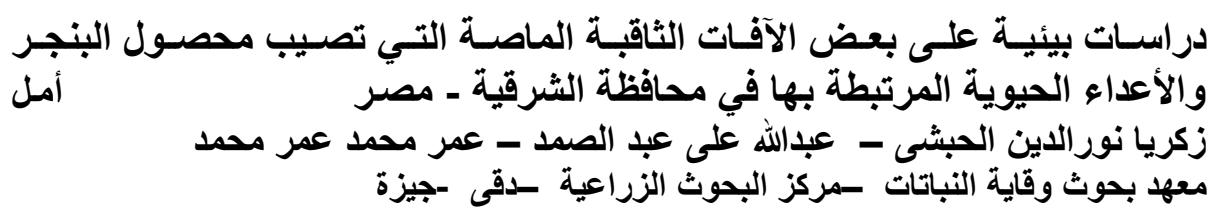

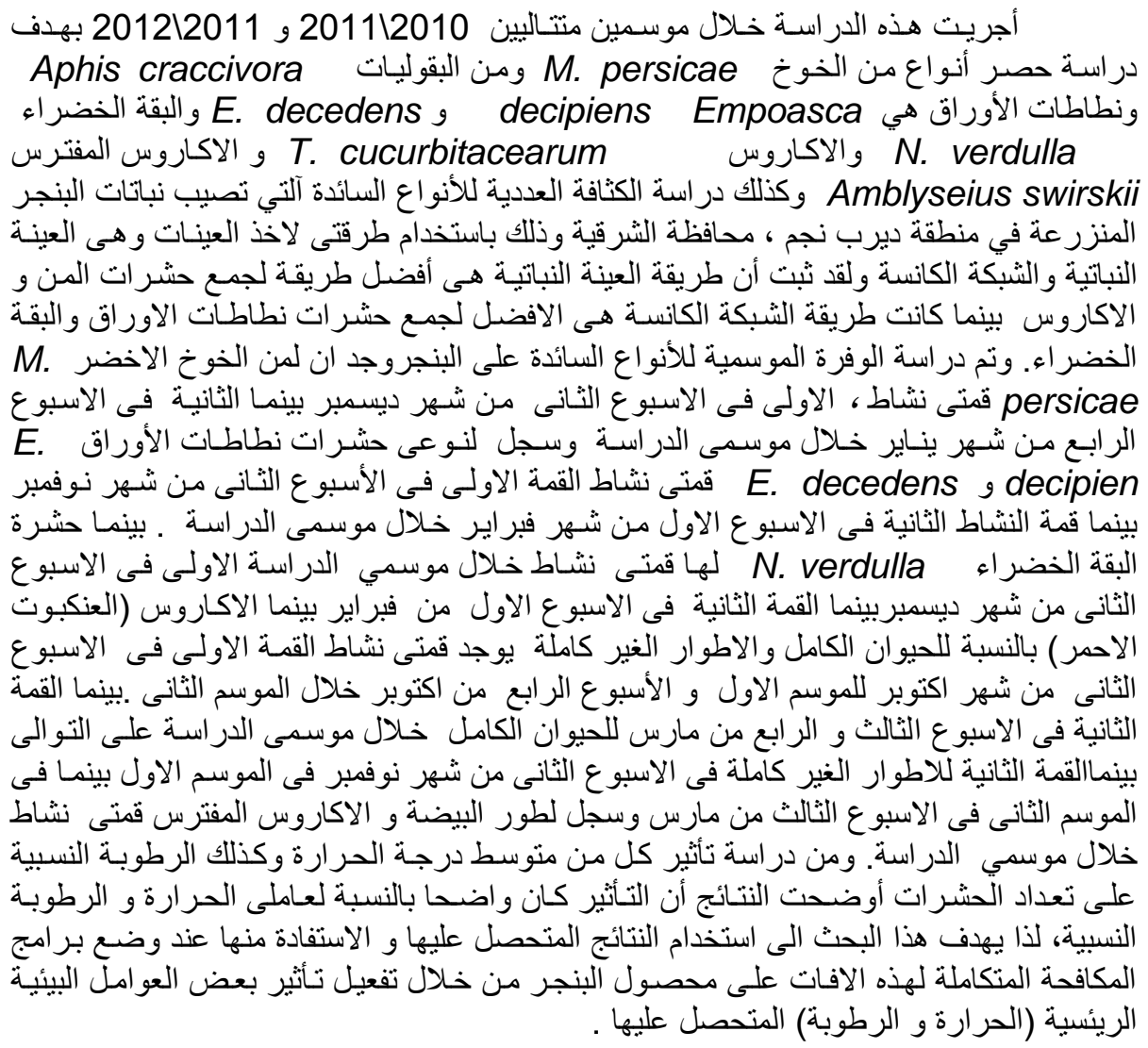

